\title{
Effects of Appropriate Composition of Sugarcane Bagasse Compost and Nitrogen Fertilizer on the Growth and Yield of Soybean (Glycine max L. Merill)
}

\author{
Maulana Yusuf \\ Department of Agrotechnology, \\ Faculty of Agriculture \\ Universitas Muhammadiyah Yogyakarta \\ Yogyakarta, Indonesia \\ yuzarsif.maulana@gmail.com
}

\author{
Sarjiyah \\ Department of Agrotechnology, \\ Faculty of Agriculture \\ Universitas Muhammadiyah Yogyakarta \\ Yogyakarta, Indonesia \\ sarjiyah@umy.ac.id
}

\author{
Mulyono \\ Department of Agrotechnology, \\ Faculty of Agriculture \\ Universitas Muhammadiyah Yogyakarta \\ Yogyakarta, Indonesia \\ mulyonosimo@gmail.com
}

\begin{abstract}
The increase of annual soybean import in Indonesia is attributed to the increase of national consumption and low production of soybean. This is mainly due to the decrease in soil fertility as a result of excessive use of synthetic fertilizer leading to the low soybean productivity and production. One of the attempts to increase soil fertility and soybean productivity is by reducing the use of synthetic fertilizer $\mathrm{N}$ and optimizing the use of organic fertilizer such as sugar cane bagasse compost rich of Nitrogen. On this account, this research aims to determine the appropriate mixture of sugar cane bagasse compost and ertilizer $N$ on the growth and yield of soybean. This research applies single factor experiment method arranged in Complete Random Design (CRD) consisting of five treatments, namely $100 \% \mathrm{~N}$ from urea (control), $25 \% \mathrm{~N}$ (sugar cane bagasse compost) $+75 \% \mathrm{~N}$ (from urea), $50 \% \mathrm{~N}$ (from sugar cane bagasse compost) $+\mathbf{5 0} \% \mathrm{~N}$ (from urea), $75 \% \mathrm{~N}$ (from sugar cane bagasse compost) $+25 \%$ $\mathrm{N}$ (from urea), $100 \% \mathrm{~N}$ (from sugar cane bagasse compost). It is revealed that the mixture of $75 \%$ sugar cane bagasse compost and $25 \%$ fertilizer $N$ from urea is the most appropriate composition for the 8.76 ton/ha soybean yield.
\end{abstract}

Keywords - N fertilizer, Soybean, sugar cane bagasse compost

\section{INTRODUCTION}

Soybean is the third and most important staple food after rice and corn. The 2016 agricultural statistics delineates that Indonesia's soybean imports continued to increase from 1.985.811 tons in 2014 to 2.261 .803 tons in 2016, while soybean production decreased from 963.183 tons in 2015 to 859.653 tons in 2016. The low soybean production in Indonesia was resulted from a functional shift of agricultural land to non-agriculture so that the planting area reduces and the soil fertility decreases due to the lack of effort to reduce the use of inorganic fertilizers in crop cultivation.

The use of inorganic fertilizer in agriculture aims to boost agricultural productivity by using modern technology. However, the use of overlong continuous inorganic fertilizers might lead to problems of reduced land productivity. [1], stated that in the 1990s, farmers had to deal with the deteriorating soil fertility due to high dependence on the use of inorganic chemical fertilizers. The most reasonable solution to reduce the use of synthetic fertilizers while improving the physical, chemical and biological nature of the soil in soybean culture is to use organic fertilizers.

As a plantation crop, sugarcane is often used as a raw material in the sugar industry. It provides by-products from both on and off-farm. The area of the sugarcane field in 2011 amounted to 418.259 ha with total national sugarcane production of 34.218.549 tons [2]. According to [3], one ton of sugarcane can produce around 300 kilograms of waste $(30 \%)$. Thus, it is assumed that the sugarcane grinding process can produce sugarcane bagasse by $32 \%$ or around 10.2 million tons of bagasse per year or milling season throughout Indonesia. The by-products from sugarcane include leaves, waste, ash, sugarcane liquid waste, and molasses. The production process at sugar mills can produce sugarcane bagasse as much as $35-40 \%$ of each processed sugarcane without taking into account molasses and water [4].

Erwin (1997) in [5], suggests that sugarcane bagasse contains organic material of $\mathrm{C}(22,4 \%), \mathrm{C} / \mathrm{N}$ ratio $(89,6 \%)$, moisture levels $(52 \%), \mathrm{N}(0,25 \%)$, phosphate levels $(0,15-$ $0,22 \%)$, and $\mathrm{K}_{2} \mathrm{O}(0,2-0,38 \%)$. The high fiber levels and $\mathrm{C}$ / $\mathrm{N}$ ratio may lead to the long decomposition process, so it requires additives to accelerate the composting process.

Defines additives for [5] as all ingredients added during the composting process with the purpose of accelerating the composting process. To reduce the high $\mathrm{C} / \mathrm{N}$ ratio in sugarcane bagasse, we can use a mixture of additives such as Azolla $(3.6 \% \mathrm{~N})$ containing high $\mathrm{N}$ which can reduce high $\mathrm{C} / \mathrm{N}$ ratio of sugarcane bagasse. The mixture of sugarcane bagasse compost using Azolla additives contains soil moisture of $(32.84 \%)$, organic matter $(28.55 \%)$, C $(16.56 \%)$, $\mathrm{N}(1.02 \%)$ and $\mathrm{C} / \mathrm{N}$ ratio (16.23) capable of substituting urea fertilizer in providing nutrients for plants, especially $\mathrm{N}$ nutrients. The high $\mathrm{N}$ content in sugarcane bagasse compost is expected to substitute the need for $\mathrm{N}$ from urea for soybean plant growth.

On this basis, this study aims to determine the appropriate composition of sugarcane bagasse compost and $\mathrm{N}$ fertilizer $\mathrm{N}$ in the growth and yield of soybean. 


\section{METHODS}

The study was conducted at the Laboratory of Soil Science and field experiment of the Faculty of Agriculture, Universitas Muhammadiyah Yogyakarta from October 2017 to March 2018. The materials used in this study were sugarcane bagasse, Azolla, Anjasmoro Varieties of soybean seeds, regosol soil and $\mathrm{N}$ (urea) fertilizer. The research was conducted using a single factor experiment arranged in Complete Random Design (RAL) consisting of five treatments: $100 \% \mathrm{~N}$ from urea (control), $25 \% \mathrm{~N}$ from sugarcane bagasse compost $+75 \% \mathrm{~N}$ from urea, $50 \% \mathrm{~N}$ from sugarcane bagasse compost $+50 \% \mathrm{~N}$ from urea, $75 \% \mathrm{~N}$ from sugarcane bagasse compost $+25 \% \mathrm{~N}$ from urea and $100 \% \mathrm{~N}$ from sugarcane bagasse compost, each of which was repeated three times.

\section{RESULTS AND DISCUSSION}

\section{A. Composting results}

The study began with the process of composting sugarcane bagasse to be used in the treatment research. The whole composting process taking place for four weeks was carefully observed to see each composting parameter. This observation resulted in the following composting composition.

On the basis of the observation, it is prominent that the composition of each parameter has met the SNI compost resulting in use-appropriate compost production, as presented in Table 1 .

\section{B. Plant height (cm)}

Plant growth is resulted from the utilization of photosynthetic nutrients used in stem cells so that over time, plants will grow and show an increase of plant height. As an illustration, the average plant height is presented in Table 2.

The analysis of variance in plant height delineates that there is no significant difference between the treatment of nutrient composition of sugarcane bagasse compost and $\mathrm{N}$ fertilizer from the given urea. The average plant height in Table 2 shows that each treatment reveals no significant difference in average values indicating that the given nutrient composition of fertilizer has the same effect on the height of soybean plants. This is due to the fact that the given the nutrient composition of sugar cane bagasse fertilizer and urea fertilizer can provide enough nutrients (especially N) for vegetative growth of plants. On this account, [6] highlighted that fertilizer N, P, K which were applied with the composition of guano fertilizer could boost the height of soybean crops. Compost has a slow release, while inorganic fertilizer is quickly released This explains why, in the first to seventh week, the plant does not experience any nutrient deficiencies.

\section{Number of leaves}

The number of leaves is defined as the total number of leaves in each plant. Leaves are one of the essential organs in plants that accommodate the process of photosynthesis to support plant growth and development. The average number of leaves is presented in Table 3 .

It is prominent that the analysis of variance in the number of leaves portrays no significant difference between the treatment of sugar cane bagasse compost and $\mathrm{N}$ fertilizer from given urea. Table 3 depicts that the average number of leaves is not significantly different one from another. Thus, it is presumable that the provision of various levels of nutrient compositions of sugarcane bagasse compost and $\mathrm{N}$ fertilizer from urea results in the same number of leaves.

The $\mathrm{N}$ nutrients contained in each treatment are believed to be optimally absorbed by the plants leading to the healthy growth of the leaves. On this account, [7] asserts that the sugarcane bagasse fertilizer may affect the height of the stem, the number of leaves and the area of green bean leaves.

\section{Root length}

Roots are defined as plant organs with a primary function of absorbing water and nutrients that generally grow beneath the soil surface. In addition to absorbing water and nutrients, the root functions as a vegetative organ to support plants growth, making them a vital organ for plants. The average root length is presented in Table 4.

The analysis of variance of root length highlights that there are no significant different effects from one treatment to another. Table 4 shows that the average values of root length in the third and seventh week shows no significant difference. That is to say that providing the plants with various composition levels of sugarcane bagasse compost and $\mathrm{N}$ fertilizer may lead to the same results. Plant roots are vegetative organs of plants which are closely related to plant height but it is revealed that the number of leaves of one treatment to another is not significantly different. This suggests that any nutrient composition of sugarcane bagasse compose and $\mathrm{N}$ fertilizer from urea can support the growth of root length in soybean crops.

\section{E. The fresh and dry weight of plants (gram)}

Fresh weight of plants is the weight of plants that is measured when the plant is harvested which describes the plant's ability to absorb water and nutrients. Meanwhile, dry weight of plants is the weight of plants measured after dried with an oven which describes the plant's ability to produce photosynthate. Fresh weight of plants is resulted from plants' metabolism during the growth period consisting of photosynthate and water absorption, while dry weight is the overall weight of plants from the canopy to the roots of photosynthesis and respiration. In the vegetative phase of plants, an increase in vegetative organs such as stems, leaves, and roots will affect the fresh and dry weight of plants. Thus, the availability of nutrients and water greatly supports the plants' growth and development that affect the fresh and dry weight of the plants. The average fresh and dry weight of plants is presented in Table 5 .

The analysis of variance in fresh and dry weight of soybean plants in the third week indicates that there are significant differences as a result of different treatments. Based on the results of further DMRT testing at the $\alpha$ level of $5 \%$ as presented in table 5 , it is revealed that in the third week, the average fresh and dry weight in the treatment using $75 \%$ compost $+25 \%$ urea witnessed the highest real number compared to the treatment using $100 \%$ urea, but not significantly different from $25 \%$ compost $+75 \%$ urea and $50 \%$ compost $+50 \%$ urea, at the medium level. Conversely, the analysis of variance in fresh and dry weight of soybean plants at week seventh pinpoints that there is no significant 
different effects of different treatments, which is due to slow organic fertilizer release.

Water is a component that significantly affects the fresh weight of plants. Most cells in plants have water content derived from moisture absorption in the planting medium. Also, the availability of $\mathrm{N}$ nutrient is very influential on the growth of stems, leaves, and roots which increases the fresh weight of plants.

At the third week, the treatment using $75 \%$ compost + $25 \%$ urea experienced the highest fresh weight followed by the treatment using $100 \%$ urea, $25 \%$ compost $+75 \%$ and $50 \%$ compost $+50 \%$. Meanwhile, the treatment of $100 \%$ compost had the lowest fresh weight. This is presumably due to the unfilled availability of $\mathrm{N}$ nutrient because organic fertilizer is slowly released preventing the application of $100 \%$ sugarcane bagasse compost from providing $\mathrm{N}$ nutrients that support vegetative growth until the third week.

At the seventh week, the fresh weight of plants in the treatment using $75 \%$ compost $+25 \%$ urea tend to be higher than the others, although the effects are not significantly different between treatments. This implies that the nutrient composition of $75 \%$ sugarcane bagasse compost and $\mathrm{N}$ fertilizer from $25 \%$ urea is the most appropriate composition to increase the fresh weight of plants. The increase in fresh weight of plants in the treatment of $75 \%$ compost $+25 \%$ urea is presumably due to the availability of nutrients and sufficient water. Fertilizer has high organic matter content, while organic matter can increase the binding capacity of the soil so that it forms a good aggregate. A suitable aggregate will increase the water holding capacity of the soil which increases soil moisture. This is reinforced by [8] stating that fertilizer has several beneficial characters, namely improving soil structure, increasing soil binding capacity and increasing the binding capacity of water on the soil.

At the third week, dry weight in $75 \%$ fertilizer $+25 \%$ urea treatment tended to be higher than other treatments. It points out that the nutrient composition of $75 \%$ sugarcane bagasse compost $+\mathrm{N}$ fertilizer from $25 \%$ urea can improve the physical content of the soil by way of increasing the water binding capacity and providing nutrients to accelerate photosynthesis to increase plant dry weight in the third week. This is different from the treatment of $100 \%$ compost that has not been able to increase the dry weight of plants in the third week. It is presumably because plants in the third week cannot use the availability of nutrients (especially $\mathrm{N}$ ) in the planting medium.

At week 7, the dry weight of plants in the treatment of $75 \%$ compost $+25 \%$ urea tended to be higher, followed by $25 \%$ compost $+75 \%$ urea, $100 \%$ urea, $100 \%$ compost and $50 \%$ compost $+50 \%$ urea. It suggests that the balance of $75 \%$ sugarcane bagasse compost $+\mathrm{N}$ fertilizer from $25 \%$ urea is the appropriate composition which can increase the dry weight of the plants.

The increase in dry weight resulted from the treatment of $75 \%$ compost $+25 \%$ urea is considered capable of processing nutrients and water as photosynthetic raw materials to produce organic compounds that support the growth rate of vegetative organs and increase the dry weight of plants. According [9] states that the increase of photosynthesis will also improve photosynthesis results of organic compounds that will be translocated to all plant organs and affect the dry weight of plants.

\section{F. Leaf area $(\mathrm{cm} 2)$}

Leaf area is one of the important parameters in the plant growth phase. Leaf area will continue to grow, and the leaf surface will be wider during its growth period [10]. Leaf area in plants will increase the number of stomata and daylight gain that can maximize plant growth. The average leaf area is presented in Table 6 .

The analysis of variance of leaf area in the third and seventh weeks shows no significant different effects between treatments. This indicates that the compositions of sugarcane bagasse fertilizer and $\mathrm{N}$ fertilizer from urea lead to the same results on the development of leaf area.

Leopold and Kriedemann [10] states that the even light received by the leaves enhances photosynthesis process to generate more numerous accumulated assimilates to support plant growth energy and to form vegetative organs such as leaves.

It suggests that the provision of $75 \%+\mathrm{N}$ sugarcane bagasse compost from $25 \%$ urea and $100 \%$ compost can increase the development of leaf area in soybean plants. The provision of sugarcane bagasse compost is believed to provide enough nutrients absorbable by plants.

$\mathrm{N}$ element is a nutrient required for the vegetative phase of the plant as a chlorophyll substance to enhance the photosynthesis process. Assimilate of photosynthesis generates carbohydrates and other organic compounds which supports the formation of plant cells heightening the development of leaf area. Based on [11] statement, N element is a primary ingredient forming amino acids and proteins used in the metabolic processes of plants that affect the growth of plant organs such as stems, leaves, and roots.

Leaf area in plants affects the occurrence of photosynthesis rate. Leaf area will increase the number of stomata that boost photosynthesis rate which is supported by the availability of nutrients and water to produce organic compounds, thereby increasing the net assimilation rate. The average net assimilation rate is presented in Table 7 .

Based on the analysis of variance in the net assimilation rate, there is no significant difference of effects between treatments. This implies that the leaf area affects the net assimilation rate in soybean plants. Giving the composition of sugarcane bagasse compost and $\mathrm{N}$ fertilizer from urea also leads to the same results at the net assimilation rate. It is presumably because the level of leaf area on the plant affects the rate of photosynthesis which supports the 1 net assimilation rate in plants. The higher the net assimilation rate of the plant, the higher the photosynthetic efficiency of plant leaves and the expected increase in net assimilation rate [12]. According to the net assimilation rate (LAB) expresses the photosynthetic efficiency of leaves in a plant.

\section{G. Flower to pod percentage}

The flower to pod percentage is the result of the total amount of flower that becomes a pod. The percentage of flower to pod is determined by observing the number of flowers per plant compared to the observations of the number of pods calculated by percent (\%) unit. The average percentage of flower to pod is presented in table 8 . Based on 
the analysis of variance in the percentage of interest, it is obvious that there is no significant difference of effects between treatments. Table 8 shows the average value percentages of flower that are not much different one from another. The composition of sugarcane bagasse compost and $\mathrm{N}$ from urea leads to the same results on the percentage of flowers to pods.

The percentage of the flowers to the pods in table 8 illustrates that each treatment result in insignificantly different percentage, of about $71.33 \%$ to $78 \%$. Each plant has a high rate of fallen flower, at about $25 \%$ accompanied by a high level of flower growth. It is presumably due to the involvement of genetic factors on each variety. In this light, [13] state that the Kawi variety had the highest number of flowers, but the highest percentage of the fall rate was $39.1 \%$, while the lowest percentage of fall interest was $6.6 \%$ indicated by the Lawit variety. The genetic factors that can produce more flowers also have more fallen flowers, indicating an involvement of genetic factors in controlling the high and low percentage of falling flowers.

\section{H. The number of pods/plant}

The number of pods is the total pod formed in each plant. The number of pods is known by counting all pods in each plant. The number of pods is an important parameter to determine the success of the flower forming pods. The number of pods formed varies from 2-20 in one flowering and more than 400 in one plant [14]. The average number of pods is presented in Table 9.

The analysis of variance in the number of pods per plant delineates no significant different effect between treatments. However, the average number of pods in Table 10 shows that $75 \%$ of compost $+25 \%$ urea has a higher average number of pods/crops than other treatments, followed by $25 \%$ compost $+75 \%$ urea, $100 \%$ compost, $100 \%$ urea and $50 \%$ compost $+50 \%$ urea. This implies that the $75 \%$ sugarcane bagasse compost and $25 \% \mathrm{~N}$ from urea can increase the number of pods in soybean plants. The increase in the treatment of $75 \%$ compost $+25 \%, 25 \%$ compost $+75 \%$ urea and $100 \%$ compost is considered to be due to the availability of $\mathrm{P}$ elements that can be absorbed optimally, thus increasing the number of pods. Suprapto [15] asserts that soybean plants will use P maximally when the plant is in the pod formation until about ten days before the seeds are fully developed.

\section{Filled pod percentage (\%)}

The percentage of filled pods is the total number of seed pods calculated by percent $(\%)$ unit. The percentage of filled pods is calculated by determining the total pods per plant divided by the total filled pods/crops and multiplied by 100 to get the units in percent $(\%)$ form. The average percentage of filled pods is presented in Table 10.

The results of the analysis of variance in filled pods percentage show that there are no significant different effects between treatments. Table 10 shows the difference in the average percentage of filled pods that is not significantly different. It shows that the applied sugarcane bagasse fertilizer gives the same results on the percentage of filled pods of soybean crops.

This implies that the composition of sugarcane bagasse compost is thought to be able to compensate for $\mathrm{N}$ fertilizer from urea. Application of balanced composition of sugarcane bagasse compost and $\mathrm{N}$ fertilizer with the appropriate dose can fertilize the soil and provide macro and micronutrients to increase soil fertility and enable the availability of nutrient absorption for the growth and development of soybean plants. According to Norman, A.G [16] $\mathrm{N}$ nutrients play an important role as a proteins substance that will be used by plants to increase the number of filled pods.

\section{J. Dry pod weight/plant (gram)}

Dry pod weight/crop is the total weight of dried pods per plant calculated by weight unit (gram, kilogram, ton, etc.). Pods that are formed in each plant have different sizes, and thus different weights. The weight of the pod is determined by weighing all the pods per plant after drying. The results of the average dry pod weight analysis are presented in Table 11 .

Based on the results of the analysis of variance in dry pod weight per plant, it is revealed that there is no significant difference between treatments. Table 11 shows that the average values are relatively different, but there is no significant difference between treatments. This implies that the provision of sugarcane bagasse fertilizer and $\mathrm{N}$ fertilizer from urea leads to the same effect on the weight of the dried pods per plant.

When linked to the number of pods per plant, it is suspected that the treatment of $100 \%$ of urea experience nutrient deficiency in the reproductive phase affects the development of plant pods. The treatment of $100 \%$ urea has pods \pm 30 pieces more than the treatment $50 \%$ compost + $50 \%$ urea. These two treatments have pod weights that are not much different $(100 \%$ urea $=64.81 \mathrm{~g}$ and $50 \%$ compost $+50 \%$ compost $=59.99 \mathrm{~g})$. However, from the number of pods/plants in the treatment of $100 \%$ compost which has \pm 30 pieces of pods more than the $100 \%$ urea treatment, it is obvious that the two treatments have a much different pod weight $(100 \%$ compost $=96.17 \mathrm{~g}$ and $100 \%$ urea $=64.81 \mathrm{~g})$.

This is also correlated to the leaf area of soybean plants. The wider the leaf area of the plant, the higher the photosynthetic rate of the plant. The high rate of photosynthesis which is supported by sufficient availability of nutrients will produce a lot of organic compounds in the form of carbohydrates that will be used by plants in the formation and development of pods. Norman, A.G. [16] report that increasing photosynthetic activity will increase the number of carbohydrates produced as food reserves in the form of pods. Plants with good fertility will be able to develop optimally in the reproductive phase, while plants with low fertility levels cannot develop optimally resulting in lighter ponds.

\section{K. The number of seeds/plant}

The number of seeds is an outcome indicator that can be used to determine the ability of soybean plants to produce seeds. Soybean seeds begin to form optimally after the pod formation has been completed. One soybean pod can contain 1-5 seeds which generally form 2-4 seeds in one pod [14]. The average number of seeds/plant is presented in Table 12 .

The analysis of variance in the number of seeds per shows that there are are no significant different effects between treatments. This implies that the composition of 
sugarcane bagasse compost and $\mathrm{N}$ fertilizer from urea leads to the same soybean seed formation.

The average number of seeds in the treatment of $75 \%$ compost $+25 \%, 100 \%$ compost and $25 \%$ compost $+75 \%$ urea tends to be higher than that in the treatment of $100 \%$ urea and $50 \%$ compost $+50 \%$ urea. It is presumably because the sugarcane bagasse compost, and $\mathrm{N}$ fertilizer from urea in the treatment of $75 \%$ compost $+25 \%$ urea, $100 \%$ compost, and $25 \%$ compost $+75 \%$ urea is the appropriate composition because it can optimize the reproductive phase of the plant.

Seed formation in soybean plants is influenced by the availability of nutrients in the planting medium. The availability of nutrients especially $\mathrm{N}$ will increase the growth rate of vegetative organs such as leaf area. The wider the leaf surface in the plant, the more the number of stomata in the leaves, so that the photosynthesis rate of plants will increase with the availability of sufficient nutrients. Increasing the rate of photosynthesis will increase the availability of carbohydrates in plants used to produce seeds in soybean plants. According to [17], increasing nutrients will produce more protein and optimal process of photosynthesis in plants, resulting in the higher availability of carbohydrates to produce more seeds. In this line, [18] state that adequate and balanced nutrient conditions in the soil will provide high yields on plants.

\section{Seed weight/plant (gram)}

Seed weight is the total weight of overall seeds of each plant measured in grams. The weight of the seeds is determined after the seeds and the water content of the seeds per plant are dried under the sun, after which the water content of each seed per plant is equalized with a moisture level of $12 \%$. The average weight of seeds per plant is presented in Table 13.

The analysis of variance in the weight of seeds per plant illustrates that there is no significant difference between the treatments. In other words, the different nutrient composition of sugarcane bagasse compost gives the same effect as $\mathrm{N}$ composting from urea on the weight of seeds per plant.

From the average seed weight per plant in Table 13, it is obvious that the weight of seeds per plant in treatment using $75 \%$ compost $+25 \%$ urea, and $100 \%$ compost and $25 \%$ compost $+75 \%$ urea tends to be higher than the treatment using $100 \%$ urea and $50 \%$ compost $+50 \%$ urea. This is an indication that the composition of sugarcane bagasse compost of $75 \%$ compost $+25 \%$ urea, and $100 \%$ compost and $25 \%$ compost $+75 \%$ urea can increase the weight of seeds per plant. Weight increase of seeds per plant in the treatment of $75 \%$ compost $+25 \%$ urea, and $100 \%$ compost and $25 \%$ compost $+75 \%$ urea is presumably due to the availability of sufficient $\mathrm{N}$ nutrients in the treatment enabling optimal absorption and protein formation that have an impact on soybean seed growth. This is in line with the research of [6], pronouncing that NPK fertilizer combined with Guano fertilizer can meet the $\mathrm{N}$ needs of plants. $\mathrm{N}$ is an essential element for protein formation needed for soybean seed growth. The $\mathrm{N}$ element is also an essential component in amino acids that form the basis of protein formation. In addition, in nitrogen bases $\mathrm{n}$ is contained in nucleic acids and related compounds, such as ATP (Adenosine triphosphate) which ultimately adds to the dry weight of the seeds [17].

\section{Seed yield (ton/ha)}

Seed yield is strongly influenced by soil fertility and spacing. Fertile soil is known to be capable of supporting increasing seeds, while spacing will determine the number of plants to grow on the land. Average seed yield is presented in Table 14. The analysis of variance in seed yields shows no significant differences between treatments. It is obvious that each treatment has the same effect on the yield of soybean seeds. The average yield of soybean seed is presented in Figure 1.

Figure 1 shows that the highest seed yield is resulted from the treatment with $75 \%$ compost $+25 \%$ urea, followed by the treatment with $100 \%$ compost and $25 \%$ compost + $75 \%$ urea. On the other hand, the treatment of $100 \%$ urea and $50 \%$ compost $+50 \%$ urea has average to low seed yields. It is conclusive that the nutrient composition of $75 \%$ sugarcane bagasse compost and $25 \% \mathrm{~N}$ fertilizer from urea can produce soybean seeds of 8.76 tons/ha. Also it is assumed that the the treatment using $75 \%$ compost $+25 \%$ urea is the appropriate composition that can increase soil fertility to optimize the growth and yield of soybean plants. According to [6] organic composting combined with $\mathrm{N}, \mathrm{P}$ and $\mathrm{K}$ fertilizers is a longterm sustainable nutrient management to improve the quality of soil fertility to subsequently raise the yield of legumes.

\section{N. Figures and Tables}

Table 1. Composting result

\begin{tabular}{|c|c|c|c|c|c|}
\hline \multirow{2}{*}{ No } & \multirow{2}{*}{ Parameter } & \multirow{2}{*}{ Unit } & \multirow{2}{*}{ Composting result } & \multicolumn{2}{|c|}{ SNI Compost } \\
\hline & & & & Minimum & Maximum \\
\hline 1 & Water content & $\%$ & 50 & & 50 \\
\hline 2 & Temperature & ${ }^{\circ} \mathrm{C}$ & 33 & & $\begin{array}{l}\text { Soil moisture } \\
\text { temperature }\end{array}$ \\
\hline 3 & Color & & Dark brown & & Blackish \\
\hline 4 & Odor & & Odor-free & & Soil smell \\
\hline 5 & $\mathrm{pH}$ & & 7.20 & 6.80 & \\
\hline 6 & Organic matter & $\%$ & 38.68 & 27 & 58 \\
\hline 7 & Nitrogen & $\%$ & 1.09 & 0.40 & - \\
\hline 8 & Carbon & $\%$ & 22.43 & 9.80 & 32 \\
\hline 9 & $\mathrm{C} / \mathrm{N}$ ratio & & 20.52 & 10 & 20 \\
\hline
\end{tabular}

Table 2. Average plant height in the $7^{\text {th }}$ week

\begin{tabular}{lc}
\hline \multicolumn{1}{c}{ Treatment } & Plant height $(\mathbf{c m})$ \\
\hline $100 \%$ urea & $98.6 \mathrm{a}$ \\
$25 \%$ compost $+75 \%$ urea & $87.8 \mathrm{a}$ \\
$50 \%$ compost $+50 \%$ urea & $107 \mathrm{a}$ \\
$75 \%$ compost $+25 \%$ urea & $89.1 \mathrm{a}$ \\
$100 \%$ compost & $87.8 \mathrm{a}$ \\
\hline
\end{tabular}

Notes: the average followed by the same alphabet shows no significant difference based on $\mathrm{F}$ test at $5 \% \alpha$.

Table 3. Average number of leaves in the $7^{\text {th }}$ week

\begin{tabular}{lc}
\hline \multicolumn{1}{c}{ Treatment } & Number of leaves \\
\hline $100 \%$ urea & $100.67 \mathrm{a}$ \\
$25 \%$ compost $+75 \%$ urea & $94.67 \mathrm{a}$ \\
$50 \%$ compost $+50 \%$ urea & $94.67 \mathrm{a}$ \\
$75 \%$ compost $+25 \%$ urea & $97.33 \mathrm{a}$ \\
$100 \%$ compost & $100.33 \mathrm{a}$ \\
\hline
\end{tabular}

Notes: the average followed by the same alphabet shows no significant difference based on $\mathrm{F}$ test at $5 \% \alpha$. 
Table 4. Average root length in the $3^{\text {rd }}$ and $7^{\text {th }}$ week

\begin{tabular}{lcc}
\multirow{2}{*}{\multicolumn{1}{c}{ Treatment }} & \multicolumn{2}{c}{ Root Length $(\mathbf{c m})$} \\
\cline { 2 - 3 } & 3mst & 7mst \\
\hline $100 \%$ urea & $31.00 \mathrm{a}$ & $62.83 \mathrm{a}$ \\
$25 \%$ compost $+75 \%$ urea & $29.50 \mathrm{a}$ & $69.50 \mathrm{a}$ \\
$50 \%$ compost $+50 \%$ urea & $29.91 \mathrm{a}$ & $56.67 \mathrm{a}$ \\
$75 \%$ compost $+25 \%$ urea & $31.50 \mathrm{a}$ & $67.67 \mathrm{a}$ \\
$100 \%$ compost & $24.25 \mathrm{a}$ & $58.83 \mathrm{a}$ \\
\hline
\end{tabular}

Notes: the average followed by the same alphabet shows no significant difference based on $\mathrm{F}$ test at $5 \% \alpha$.

Table 5. Average fresh and dry weight of plant in the $3^{\text {rd }}$ and $7^{\text {th }}$ week

\begin{tabular}{lcccc} 
& \multicolumn{4}{c}{ Fresh Weight and Dry Weight $(\mathbf{g})^{*}$} \\
\cline { 2 - 5 } Treatment & 3mst & 3mst & 7mst & 3mst \\
\hline $100 \%$ urea & $6.76 \mathrm{ab}$ & $0.78 \mathrm{ab}$ & $79.00 \mathrm{a}$ & $17.91 \mathrm{a}$ \\
$25 \%$ compost $+75 \%$ urea & $6.07 \mathrm{ab}$ & $0.75 \mathrm{ab}$ & $78.83 \mathrm{a}$ & $18.85 \mathrm{a}$ \\
$50 \%$ compost $+50 \%$ urea & $6.34 \mathrm{ab}$ & $0.84 \mathrm{ab}$ & $55.37 \mathrm{a}$ & $12.32 \mathrm{a}$ \\
$75 \%$ compost $+25 \%$ urea & $7.93 \mathrm{a}$ & $1.03 \mathrm{a}$ & $109.60 \mathrm{a}$ & $21.28 \mathrm{a}$ \\
$100 \%$ compost & $3.88 \mathrm{~b}$ & $0.47 \mathrm{~b}$ & $79.00 \mathrm{a}$ & $16.32 \mathrm{a}$ \\
\hline Notes: the average followed by the same alphabet shows no significant difference based \\
on F test at 5\% $\alpha$. \\
*Data results transformed using Arc. Sin.
\end{tabular}

Table 6. Average leaves area in the $3^{\text {rd }}$ and $7^{\text {th }}$ week

\begin{tabular}{lcc}
\multirow{2}{*}{\multicolumn{1}{c}{ Treatment }} & \multicolumn{2}{c}{ Leaf Area $\left(\mathbf{c m}^{2}\right)^{*}$} \\
\cline { 2 - 3 } & 3mst & 7mst \\
\hline $100 \%$ urea & $171.33 \mathrm{a}$ & $1905.0 \mathrm{a}$ \\
$25 \%$ compost $+75 \%$ urea & $161.33 \mathrm{a}$ & $1810.5 \mathrm{a}$ \\
$50 \%$ compost $+50 \%$ urea & $170.50 \mathrm{a}$ & $1436.0 \mathrm{a}$ \\
$75 \%$ compost $+25 \%$ urea & $181.50 \mathrm{a}$ & $2203.5 \mathrm{a}$ \\
$100 \%$ compost & $93.00 \mathrm{a}$ & $1916.0 \mathrm{a}$ \\
\hline
\end{tabular}

Notes: the average followed by the same alphabet shows no significant difference based on $\mathrm{F}$ test at $5 \% \alpha$.

*Data results transformed using Arc. Sin.

Table 7. Average net assimilation rate in the $3^{\text {rd }}$ and $7^{\text {th }}$ week

\begin{tabular}{lc}
\hline \multicolumn{1}{c}{ Treatment } & $\begin{array}{c}\text { Net Assimilation Rate } \\
\left(\mathbf{g} / \mathbf{c m}^{2} / \text { week }\right)\end{array}$ \\
\hline $100 \%$ urea & $2.52 \mathrm{a}$ \\
$25 \%$ compost $+75 \%$ urea & $2.95 \mathrm{a}$ \\
$50 \%$ compost $+50 \%$ urea & $1.54 \mathrm{a}$ \\
$75 \%$ compost $+25 \%$ urea & $3.28 \mathrm{a}$ \\
$100 \%$ compost & $3.04 \mathrm{a}$ \\
\hline
\end{tabular}

Notes: the average followed by the same alphabet shows no significant difference based on $\mathrm{F}$ test on $5 \% \alpha$. *Data results transformed using Arc. Sin.
Table 8. Average flower to pod percentage

\begin{tabular}{lc}
\hline \multicolumn{1}{c}{ Treatment } & $\begin{array}{c}\text { Flower to Pod } \\
\text { Percentage }(\%)\end{array}$ \\
\hline $100 \%$ urea & $76.67 \mathrm{a}$ \\
$25 \%$ compost $+75 \%$ urea & $78.00 \mathrm{a}$ \\
$50 \%$ compost $+50 \%$ urea & $72.67 \mathrm{a}$ \\
$75 \%$ compost $+25 \%$ urea & $77.67 \mathrm{a}$ \\
$100 \%$ compost & $71.33 \mathrm{a}$ \\
\hline
\end{tabular}

Notes: the average followed by the same alphabet shows no significant difference based on $\mathrm{F}$ test at $5 \% \alpha$.

Table 9. Average number of pods/plant

\begin{tabular}{lc}
\hline \multicolumn{1}{c}{ Treatment } & Number of Pods/Plant \\
\hline $100 \%$ urea & $202.34 \mathrm{a}$ \\
$25 \%$ compost $+75 \%$ urea & $231.89 \mathrm{a}$ \\
$50 \%$ compost $+50 \%$ urea & $165.00 \mathrm{a}$ \\
$75 \%$ compost $+25 \%$ urea & $252.67 \mathrm{a}$ \\
$100 \%$ compost & $225.44 \mathrm{a}$ \\
\hline
\end{tabular}

Notes: the average followed by the same alphabet shows no significant difference based on $\mathrm{F}$ test at $5 \% \alpha$.

Table 10. Average filled pod percentage

\begin{tabular}{lc}
\hline \multicolumn{1}{c}{ Treatment } & $\begin{array}{c}\text { Filled Pod Percentage } \\
(\%)\end{array}$ \\
\hline $100 \%$ urea & $75.33 \mathrm{a}$ \\
$25 \%$ compost $+75 \%$ urea & $83.33 \mathrm{a}$ \\
$50 \%$ compost $+50 \%$ urea & $71.00 \mathrm{a}$ \\
$75 \%$ compost $+25 \%$ urea & $88.00 \mathrm{a}$ \\
$100 \%$ compost & $81.33 \mathrm{a}$ \\
\hline
\end{tabular}

Notes: the average followed by the same alphabet shows no significant difference based on $\mathrm{F}$ test at $5 \% \alpha$.

Table 11. Average dry pod weight/plant

\begin{tabular}{lc}
\hline \multicolumn{1}{c}{ Treatment } & Dry Pod Weight (gr)* \\
\hline $100 \%$ urea & $64.81 \mathrm{a}$ \\
$25 \%$ compost $+75 \%$ urea & $96.17 \mathrm{a}$ \\
$50 \%$ compost $+50 \%$ urea & $59.99 \mathrm{a}$ \\
$75 \%$ compost $+25 \%$ urea & $101.56 \mathrm{a}$ \\
$100 \%$ compost & $89.81 \mathrm{a}$ \\
\hline
\end{tabular}

Notes: the average followed by the same alphabet shows no significant difference based on $\mathrm{F}$ test at $5 \% \alpha$. *Data results transformed using Arc. Sin.

Table 12. Average number of seeds/plant

\begin{tabular}{lc}
\hline \multicolumn{1}{c}{ Treatment } & Number of Seeds/Plant* \\
\hline $100 \%$ urea & $272.77 \mathrm{a}$ \\
$25 \%$ compost $+75 \%$ urea & $387.77 \mathrm{a}$ \\
$50 \%$ compost $+50 \%$ urea & $247.44 \mathrm{a}$ \\
$75 \%$ compost $+25 \%$ urea & $429.22 \mathrm{a}$ \\
$100 \%$ compost & $396.77 \mathrm{a}$ \\
\hline
\end{tabular}

Notes: the average followed by the same alphabet shows no significant difference based on $\mathrm{F}$ test at $5 \% \alpha$. *Data results transformed using Arc. Sin. 
Table 13. Average weight of seeds/plant

\begin{tabular}{lc}
\hline \multicolumn{1}{c}{ Treatment } & Seed Weight $(\mathbf{g})^{*}$ \\
\hline $100 \%$ urea & $42.90 \mathrm{a}$ \\
$25 \%$ compost $+75 \%$ urea & $65.61 \mathrm{a}$ \\
$50 \%$ compost $+50 \%$ urea & $38.87 \mathrm{a}$ \\
$75 \%$ compost $+25 \%$ urea & $70.08 \mathrm{a}$ \\
$100 \%$ compost & $62.33 \mathrm{a}$ \\
\hline
\end{tabular}

Notes: the average followed by the same alphabet shows no significant difference based on $\mathrm{F}$ test at $5 \% \alpha$. *Data results transformed using Arc. Sin.

Table 14. Average seed yield

\begin{tabular}{lc}
\hline \multicolumn{1}{c}{ Treatment } & Seed Yield (ton $/ \mathbf{h a})^{*}$ \\
\hline $100 \%$ urea & $5.36 \mathrm{a}$ \\
$25 \%$ compost $+75 \%$ urea & $8.20 \mathrm{a}$ \\
$50 \%$ compost $+50 \%$ urea & $4.86 \mathrm{a}$ \\
$75 \%$ compost $+25 \%$ urea & $8.76 \mathrm{a}$ \\
$100 \%$ compost & $7.79 \mathrm{a}$ \\
\hline
\end{tabular}

Notes: the average followed by the same alphabet shows no significant difference based on $\mathrm{F}$ test at $5 \% \alpha$.

*Data results transformed using Arc. Sin.

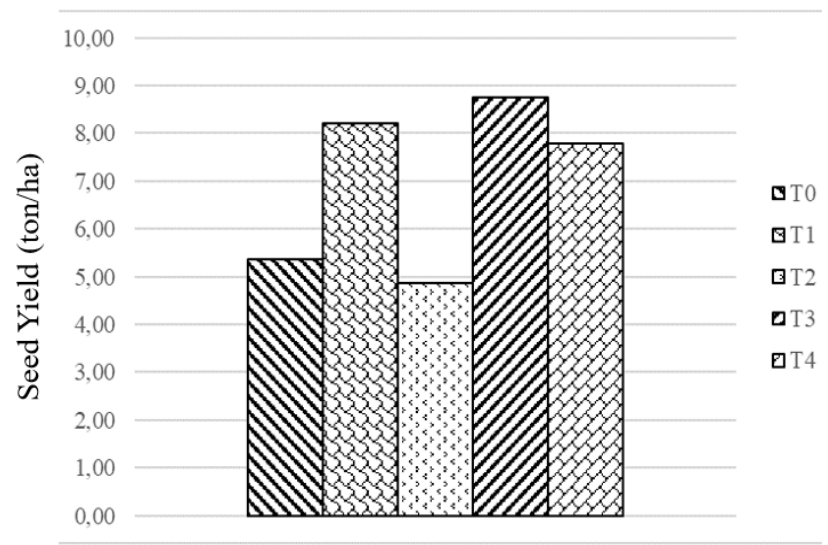

Figure 1. The average seed yield (ton/ha)

\section{CONCLUSION}

It is conclusive that the nutrient composition of $75 \%$ sugarcane bagasse compost and $\mathrm{N}$ fertilizer from $25 \%$ urea is appropriate for a soybean yield of 8.76 tons/ha.

However, it is necessary to conduct further research to determine the effect of sugarcane bagasse compost on Anjasmoro Variety soybean crops.

\section{ACKNOWLEDGMENT}

The authors would like to exert gratitude to Universitas Muhammadiyah Yogyakarta and and PT. Indofood Tbk. for financially supporting this research. The research grant was awarded by Indofood Riset Nugraha.

\section{REFERENCES}

[1] Lilis. M. R. 2015. Kerusakan tanah akibat penggunaan pupuk kimia berlebih pada lahan pertanian. Fakultas Pertanian Universitas Jember. Jawa Timur.
[2] Ditjenbun Direktorat Jenderal Perkebunan. 2011. Menteri Pertanian: peranan perkebunan tetap penting, Direktorat Jenderal Perkebunan. Retrieved from: http://www.ditjenbun.deptan.go.id/ on 19 April 2017.

[3] Subiyono. 2014. Agar pabrik gula efisien, PTPN X optimalkan ampas tebu. Agrofarm edisi Rabu, 20 Agustus 2014. Retrieved from: http://www.agrofarm.co.id/read/perkebunan/753/\#.VD-_0WeSyn0/ on 19 April 2017.

[4] Witono, J. A. 2008. Produksi Furfural Dan Turunannya Alternatif Peningkatan Nilai Tambah Ampas Tebu Indonesia. Retrieved from: http://www.chem-is-try.org/artikel kimia/teknologi tepat_guna/pro duksi furfural dan turunannya alternatif peningkatan nilai tamba h_ampas tebu indonesia/ on 19 April 2017.

[5] Shandy N. R. 2017. Percepatan Pengomposan Bagasse Tebu Dengan Penambahan Berbagai Macam Campuran Bahan Aditif. Fakltas Pertanian Universitas Muhammadiyah Yogyakarta. Yogyakarta.

[6] Wahyudin, A. F.Y. Wicaksono. A.W. Irwan. Ruminta. R. Fitriani. 2017. Respons Tanaman Kedelai (Glycine max) Varietas Wilis Akibat Pemberian Berbagai Dosis Pupuk N, P, K, dan Pupuk Guano Pada Tanah Inceptisol Jatinangor. Jurnal Kultivasi 16(2). Universitas Padjadjaran. Retrieved from: http://jurnal.unpad.ac.id/kultivasi/article/download/13223/6677/ on 19 Februari 2018

[7] Fitriana, D. K., Indrawati P., Prasetyo Wibowo, E, A. 2010 Pengaruh Pupuk Limbah Ampas Tebu (Saccharum sp) Terhadap Pertumbuhan Kacang Hijau (Phaseolus vulgaris). Universitas Negeri Semarang. Retrieved from: http://jurnal.unimus.ac.id/index.php/psn12012010/article/download/ 2291/2271/. on 19 Februari 2018.

[8] Indriani, Y. H. 2007. Membuat Kompos Secara Kilat. Penebar Swadaya. Jakarta.

[9] Salisbury F.B. dan Ross C.W.1995. Plant Physiology.Translator Diah R.L dan Sumaryono. ITB Publishing. Bandung.

[10] Leopold, A.C and Kriedemann, P.E. 1975. Plant Growth and Development. Tata Mc Graw Hill Publishing Company LTD. New York. $545 \mathrm{p}$.

[11] Lakitan, B. 1995. Fisiologi Pertumbuhan dan Perkembangan Tanaman. Raja Grafindo Persada. Jakarta.

[12] Suprihaty, P. N., Darwis,. Khaeruni, R. A. 2012. Potensi Rizobakteri Indigeneus Tanah Ultisol Sebagai Agen Pengendali hayati Penyakit Layu Sklerotium dan Pemacu Pertumbuhan Tanaman Kedelai. (1) 2 Hal. 148-155 ISSN: 2089-9858. Universitas Halu Oleo. Retrieved from:

http://faperta.uho.ac.id/berkala gronomi/Fulltext/2012/BPA010214 8.pdf/on 26 April 2018.

[13] Suyamto dan Musalamah. 2010. Kemampuan Berbunga, Tingkat Keguguran Bungan dan Potensi Hasil Beberapa Varietas kedelai. Buletin Plasma Nutfah (16) : 1.

[14] Sumarno dan M. Muchlish. 2016. Strategi Pengembangan Produksi Мепији Swasembada Kedelai Berkelanjutan. Retrieved from: file://C:/Users/RedBorn/Downloads/Materi\%20Kedelai/04sumarno .pdf/. on 19 April 2017.

[15] Suprapto, H.S. 1992. Bertanam Kedelai. PT. Penebar Swadaya. Jakarta.

[16] Norman, A.G. 1978. Soybean Physiology Agronomi and Utilization. Academic Press. New York. 249 p.

[17] Gardner, F. P., R. B. Pearce dan R. L. Mitchell. 1991. Physiology of Crop Plants. Trans. Susilo, Herawati. Universitas Indonesia (UIPress). Jakarta. p 428

[18] Fitter, A.H. and Hay, R.K.M. 1992. Fisiologi Lingkungan Tanaman. Gajah Mada University Press. Yogyakarta. 421 p. 